\title{
Prevalence of human papillomaviruses in lung carcinomas: a study of 218 cases
}

\author{
Cyrille J Coissard ${ }^{1,2}$, Guillaume Besson ${ }^{2}$, Myriam C Polette ${ }^{1,2}$, Michel Monteau ${ }^{3}$, \\ Philippe L Birembaut ${ }^{1,2}$ and Christine E Clavel ${ }^{1,2}$ \\ ${ }^{1}$ Institut National de la Santé et de la Recherche Médicale (INSERM) UMR-S 514, Reims, France; ${ }^{2}$ Laboratoire \\ Pol BOUIN, Hôpital de la Maison Blanche CHU, Reims, France and ${ }^{3}$ Polyclinique Courlancy, Reims, France
}

\begin{abstract}
High-risk human papillomaviruses (HPV) are largely implicated in the carcinogenesis of cervical carcinomas. Their role in bronchopulmonary carcinomas is still unclear. In the present study, we have explored 218 fresh frozen lung tumours for the presence of HPV with the Roche line blot assay and for the expression of mRNAs encoding E6 oncoprotein in HPV positive tumours. Only four samples were positive for HPV detection, one poorly differentiated squamous cell carcinoma and three large cell carcinomas. E6 mRNA was undetectable in these four samples. Our data confirm the low prevalence of HPV in lung carcinomas in Western European countries and do not plead in favour of a carcinogenic role for HPV in these carcinomas. Modern Pathology (2005) 18, 1606-1609. doi:10.1038/modpathol.3800472; published online 29 July 2005
\end{abstract}

Keywords: human papillomavirus; lung carcinoma; HPV genotyping; mRNA expression

Human papillomaviruses (HPV) are small doublestranded and nonenveloped DNA viruses. They are epitheliotropic and associated with both benign and malignant lesions such as papillomas, condylomas and carcinomas. HPVs belong to a heterogeneous group of viruses including oncogenic or high risk, and nononcogenic or low risk, HPV (HR-HPV and LR-HPV, respectively). HR-HPV are considered to be responsible for cervical cancer ${ }^{1,2}$ and for most carcinomas of the anogenital area. HR-HPV also play a role in malignant proliferation in other organs such as head and neck cancers and especially tonsil carcinomas. ${ }^{3,4}$ In consequence, it has been suggested that HPV could also be found in other areas where the presence of a junctional epithelium could lead to an HPV infection. The fact that HPV can be found in the tonsil and that condyloma-like lesions exist in the bronchi, led us to look for the presence of HPV in bronchopulmonary carcinomas. Indeed, as in the squamo-columnar junction of the cervix or the anorectal juction, the respiratory epithelium of smokers shows microabrasions ${ }^{5}$ with squamo-columnar junctions that are considered to be the prerequisite for the spread of HPV. ${ }^{6}$ Previously, numerous studies had been undertaken principally

Correspondence: Dr C Clavel, PhD, Laboratoire Pol BOUIN, Hôpital de la Maison Blanche, 45 rue Cognacq-Jay, CHU, 51100 Reims, France.

E-mail: cclavel@chu-reims.fr

Received 16 May 2005; accepted 15 June 2005; published online 29 July 2005 on squamous cell carcinoma of the lung, but according to the literature the link between HPV and carcinogenesis of lung cancers remains unclear. ${ }^{7}$

In a previous study in our laboratory, the Hybrid Capture II technique was used for the detection of HPV on 185 lung tumours. ${ }^{8}$ Although it is highly sensitive, this technique can be defective ${ }^{9,10}$ missing some HPV-HR infections. Moreover, this technique does not allow the genotyping of HPV. Thus, the aim of the present study was on the one hand to detect and to genotype HPV in a large series of 218 fresh frozen lung carcinomas using a novel PCR technique previously used on genital samples ${ }^{11-13}$ and on the other hand to assess the expression of the mRNA encoding HPV E6 oncoprotein, when HPV DNA was detected.

\section{Materials and methods}

\section{Patients and Samples}

A total of 218 patients were examined in the Polyclinic Courlancy (Reims, France). Patients' mean age was 61.2 years (range 33-78 years), with 29 women and 189 men, and all were smokers.

Lung resected for primary tumours gave fresh samples that were immediately frozen in nitrogen. These include 126 squamous cell carcinomas (49 stage I, 41 stage II and 37 stage III according to the World Health Organisation (WHO) classification), 80 adenocarcinomas (AC), including 14 bronchioalveolar carcinomas according to the WHO definition 
(42 stage I, 15 stage II, 22 stage III and 1 stage IV), 11 large cells carcinomas (three stage I, three stage II and five stage III) and one atypical carcinoid stage I. A frozen section was systematically performed to have a good representation of the histology of the tumours and to validate the viability of the sample before PCR.

\section{Detection and Typing of HPV DNA}

Total DNA was extracted using the QIAGEN DNeasy Tissue Kit (catalogue no. 69506; QIAGEN S.A., Courtaboeuf, France) following the manufacturer's instructions. The DNA samples were then put through a program of successive temperature changes to release potential impurities from the DNA. This program, originally used with the Gene Fizz reagent from Laboratoires EUROBIO (Les Ulis, France), consisted in a cycle of $30 \mathrm{~s}$ at $65^{\circ} \mathrm{C}, 30 \mathrm{~s}$ at $8^{\circ} \mathrm{C}, 1.5 \mathrm{~min}$ at $65^{\circ} \mathrm{C}, 3 \mathrm{~min}$ at $97^{\circ} \mathrm{C}, 1 \mathrm{~min}$ at $8^{\circ} \mathrm{C}$, $3 \mathrm{~min}$ at $65^{\circ} \mathrm{C}, 1 \mathrm{~min}$ at $97^{\circ} \mathrm{C}, 1 \mathrm{~min}$ at $65^{\circ} \mathrm{C}$ and $10 \mathrm{~min}$ at $85^{\circ} \mathrm{C}$. This cycle was repeated 20 times. The amount of DNA was measured with a UV spectrophotometer (Ultrospec III, Pharmacia) and the samples were then stored at $-20^{\circ} \mathrm{C}$ for further experiments.

The detection and typing of the HPV DNA was performed using the ROCHE line blot assay. This assay is based on a PCR followed by a blotting of the PCR products and allows the typing of $21 \mathrm{HR}-\mathrm{HPV}$ (16, 18, 26, 31, 33, 35, 39, 45, 51, 52, 53, 56, 58, 59, $66,67,68,70,73$ and 82$)$ and $16 \operatorname{LR}-\operatorname{HPV}(6,11,40$, $42,54,55,57,61,62,64,71,72,81,83,84$ and CP6108). The PCR is based on the PGMY primer set combined with the B-PCO4 and B-GH20 primers as described earlier ${ }^{11}$ and produces two fragments of, respectively, 450 and $268 \mathrm{bp}$. In all, 200-600 ng DNA, were engaged in each PCR. Distilled water as negative control and DNA extracted from baculoviruses having integrated different types of known HPV as positive controls were included in each PCR run. The amplicons produced were analysed with a line blot assay as described by Gravitt et $a l^{12}$ with the difference that this one was able to detect more HPV genotypes.

\section{Determination of the HPV16 Viral Load by Real-Time PCR}

The determination of the HPV16 viral load using hydrolysis probes was performed as described previously, ${ }^{14}$ with that differences that the experiences were run on the iCycler $\mathrm{iQ}^{\mathrm{TM}}$ (BIO-RAD, Marnes-la-Coquette, France), using the qPCR ${ }^{\mathrm{TM}}$ Mastermix-No ROX (EUROGENTEC, Seraing, Belgium) in a $50 \mu \mathrm{l}$ final volume. The data collected with the iCycler $\mathrm{iQ}^{\mathrm{TM}}$ were analysed with the iCycler $\mathrm{iQ}^{\mathrm{TM}}$ Real-time PCR Detection System Software version3.0A (BIO-RAD).

\section{Detection of HPV mRNA by RT-PCT}

The RNA was extracted using the QIAGEN RNeasy Midi Kit (catalogue no. 75144; QIAGEN S.A., Courtaboeuf, France) following the manufacturer's instructions. The amount and the quality of RNA were measured with a UV spectrophotometer (Ultropec III, Pharmacia) and the samples were then frozen at $-80^{\circ} \mathrm{C}$ until further experiments.

The detection of the HPV E6 mRNA was accomplished using two primers targeting the differential spliced E6 transcripts: HPV16-3 primer (5'-CAAGCA-ACA-GTT-ACT-GCG-ACG-TG-3') as the sense primer specific for nucleotides 202-224, and HPV16-4 primer (5'-TCC-GGT-TCT-GCT-TGT-CCAGCT-GG-3') as the antisense primer specific for nucleotides 704-725 of the HPV16 to produce two fragments of, respectively, 321 and $204 \mathrm{bp}$. Since SiHa and CaSki cell lines are human cervical carcinoma cell lines known to carry transcriptionally active HPV16 genome, ${ }^{15}$ RNA from SiHa cells and CaSki cells were extracted under the same conditions as the samples and used as positive controls and distilled water was the negative control. Using the Reverse Transcriptase RNA PCR Kit (Applied Biosystems) using the manufacturer's instructions, the cycling conditions were as follows: for the $\mathrm{RT}$ reaction $15 \mathrm{~min}$ at $70^{\circ} \mathrm{C}$ and $5 \mathrm{~min}$ at $4^{\circ} \mathrm{C}$. The PCR program was $1 \mathrm{~min}$ at $95^{\circ} \mathrm{C}$, a cycle repeated 45 times consisting of $1 \mathrm{~min}$ at $94^{\circ} \mathrm{C}, 30 \mathrm{~s}$ at $55.5^{\circ} \mathrm{C}$ and $30 \mathrm{~s}$ at $72^{\circ} \mathrm{C}$. The last step was followed by a $3 \mathrm{~min}$ incubation at $72^{\circ} \mathrm{C}$. The products were analysed on a SYBRgold stained gel electrophoresis.

\section{Results}

The histological examination of the 218 tumours looking for morphological changes evocating HPV infection revealed the presence of koilocytosis and papillary exophytic lesions in only five squamous cell carcinomas (four men and one woman).

Out of the 218 DNA samples tested only four (2\%) showed the presence of HPV DNA. In these four HPV-positive cases, three were large cell carcinomas. Two of them were staged III (one man 65 years old and one woman 37 years old) and one man (57 years old) staged I. The last HPV positive sample was a poorly differentiated squamous cell carcinoma staged I from a man who was 42 years old. Interestingly, the HPVs detected were in all cases HPV16 which is known to be the most involved in cervical and tonsillar carcinoma.

In these four HPV-DNA-positive cases, the presence of HPV16 was confirmed by real-time PCR which demonstrated a very low viral load (one copy per $10^{3}$ cells). Moreover, the presence and the conservation of RNA was assessed by the detection of 28S RNA. Then the detection of HPV16 mRNA was undertaken to determine the expression of the viral oncoprotein E6 mRNA. No HPV16 E6 mRNA 
was detected in these samples, whereas controls were all positive for E6 mRNA detection.

Clinically, all these patients were smokers. After a new histological examination of the frozen sections of the tumours used prior to PCR, no koilocytes and/ or other signs of viral infection were detected in the HPV-positive samples, while the five tumours with koilocytosis and papillary structures were all negative for HPV detection.

\section{Discussion}

The present study on a series of 218 lung carcinomas clearly confirms the low incidence of HPV infection in lung carcinomas. This series is one of the most important in the literature. In other studies, the prevalence of HPV in lung carcinomas ranges from 0 to $100 \% .^{7}$ The high heterogeneity of these results can be largely explained by the mode of sampling: in fresh frozen tissue samples the DNA is less degraded than in paraffin-embedded tissues where it can be fragmented and/or modified and thus is very difficult to work with. Several techniques with different sensibilities and specificities have been used to detect HPV. Historically, in situ hybridization was first used but its sensitivity is weak detecting approximately 20 to 50 copies per cell. Most studies have then used PCR, which is much more sensitive, but with difficulties to obtain large amplimers, notably when paraffin-embedded tissues are used and still again with high discrepancies. ${ }^{7}$ That is why in our study fresh frozen tissues were chosen. Moreover, the PCR technique used in our present work has been validated in numerous studies in cervical pathology. It gives medium size amplimers of 268 and $450 \mathrm{bp}$ and displays a sensitivity of at least $10 \mathrm{HPV}$ copies per PCR for HPV6, 11, 16, 18, 26, 31, 33, 35, 40, 45, 51, 52, 56 and $59^{11}$ eventhough the primers and probes used in this technique do not exclude the presence of other cutaneous HPV types. Another way to understand the important differences between the results published in the literature is by the size of the cohorts studied. Indeed, the cohorts explored in previous studies show a range from $1^{16-19}$ to $285^{20}$ cases allowing large discrepancies. In addition to these factors, the geographic and environmental variations may account for the variable results reported..$^{21,22}$ For example, HPV infection has been largely detected in Asiatic countries (Japan and China). A recent study in French patients failed to detect any HPV DNA in 122 lung carcinomas. ${ }^{23}$ In consequence, the prevalence of HPV infection in such carcinomas is a subject difficult to apprehend but in our experience is very low in our geographic area.

The presence of HPV in lung carcinomas has been mostly observed in squamous cell carcinoma. It is also sometimes associated with koilocytosis. In our series, HPV16 has been found in three large cell carcinomas and one poorly differentiated squamous cell carcinoma. The presence of HPV in large cell carcinomas is unusual since it has been reported in only two studies ${ }^{24,25}$ with the presence of HPV16 in one case and of HPV31-33 in two cases. Of particular interest is the absence of koilocytes in all our positive cases. Such observations are similar in invasive cervical squamous cell carcinomas which rarely show koilocytosis. In another way, five papillary squamous cell carcinomas in our series showed indirect classical signs of viral infection such as exophytic proliferations with koilocytosis and were negative for HPV detection. Thus, all these morphological findings together with a low prevalence of HPV detection do not plead in favour of a direct involvement of HPV in lung carcinogenesis.

However, the carcinogenic role of HPV has been previously emphasized in vitro with the use of bronchial cell lines transfected with full-length HPV16 or 18 or HPV16 E6 and E7 genes. ${ }^{26-28}$ Indeed after oncogenic HPV transfection, bronchial cell lines (BEP2D) were immortalized and showed terminal differentiation of keratinocytes, but they were not tumourigenic in nude mice. In another way, HPV16 transfection of lung adenocarcinoma (PC14) cells induced squamous metaplasia when injected into severely combined immunodeficient mice. ${ }^{29}$ Consequently, in few cases, HPV could be involved in the multistep bronchial carcinogenesis. Nevertheless, in our present study we failed to detect any oncoprotein E6 mRNA expression in the four cases positive for HPV16. In the literature, there is only one paper reporting the expression of E6/E7 mRNA of HPV18 in one SSC and two adenocarcinomas in Japan. ${ }^{30}$ Thus, the absence of oncoprotein E6 mRNA expression and of viral-induced morphological changes such as koilocytosis in the rare HPV16 positive cases pleads in favour of a simply opportunistic presence of HPV in lung carcinomas. Moreover, the mode of contamination in HPVpositive cases remains unclear. Considering our results, contrary to upper aerodigestive tract carcinomas, the effective role of HPV infection in the carcinogenesis of lung tumours is very limited in Western European countries.

\section{Acknowledgements}

We are grateful to the Lion's Club from Soissons and the Lion's club from Villers-Cotterets who have supported a part of this work. We thank ROCHE Molecular Diagnostic who supplied chemicals and reagents for the HPV genotyping. Cyrille Coissard is supported by a grant from the University of Reims.

\section{References}

1 Walboomers JMM, Jacobs MV, Manos MM, et al. Human papillomavirus is a necessary cause of invasive cancer worldwide. J Pathol 1999;189:12-19. 
2 Duggan MA. A review of the natural history of cervical intraepithelial neoplasia. Jpn J Cancer Chemother 2002;29:176-193.

3 Syrjanen S. HPV infections and tonsillar carcinoma. J Clin Pathol 2004;57:449-455.

4 De Villiers EM, Gunst K, Stein H, et al. Esophageal squamous cell cancer in patients with head and neck cancer: prevalence of human papillomavirus DNA sequences. Int J Cancer 2004;109:253-258.

5 Auerbach O, Garfinkel L, Parks VL. Histologic type of lung cancer in relation to smoking habits, year of diagnosis and site of metastasis. Chest 1975;67: 382-389.

6 Kashima H, Mounts P, Leventhal B, et al. Sites of predilection in recurrent respiratory papillomatosis. Ann Otol Rhinol Laryngol 1993;102:580-583.

7 Syrjanen KJ. Infections and lung cancer. J Clin Pathol 2002;55:885-891.

8 Clavel CE, Nawrocki B, Bosseaux B, et al. Detection of human papillomavirus DNA in bronchopulmonary carcinomas by Hybrid Capture II. A study of 185 tumors. Cancer 2000;88:1347-1351.

9 Jonhson T, Bryder K, Corbet S, et al. Routine genotyping of human papillomavirus samples in Denmark. APMIS 2003;111:398-404.

10 Lonky NM, Felix JC, Naidu YM, et al. Triage of atypical squamous cells of undetermined significance with hybrid capture II: colposcopy and histologic human papillomavirus correlation. Obstet Gynecol 2003;101: 481-489.

11 Gravitt PE, Peyton CL, Alessi TQ, et al. Improved amplification of genital human papillomaviruses. J Clin Microbiol 2000;38:357-361.

12 Gravitt PE, Peyton CL, Apple RJ, et al. Genotyping 27 human papillomavirus types by using L1 consensus PCR products by a single-hybridization, reverse line blot detection method. J Clin Microbiol 1998;36: 3020-3027.

13 Coutlée F, Gravitt P, Kornegay J, et al. The Canadian Women's HIV Study Group, Franco E. Use of PGMY primers in L1 consensus PCR improves detection of human papillomavirus DNA in genital samples. J Clin Microbiol 2002;40:902-907.

14 Prétet JL, Dalstein V, Monnier-Benoit S, et al. High risk HPV load estimated by Hybrid Capture II $^{\circledR}$ correlates with HPV16 load measured by real-time PCR in cervical smears of HPV16-infected women. J Clin Virol 2004;31:140-147.

15 Baker CC, Phelps WC, Lindgren V, et al. Structural and transcriptional analysis of human papillomavirus type 16 sequences in cervical carcinoma cell lines. J Virol 1987;61:962-971.

16 Bejui-Thivolet F, Chardonnet Y, Patricot LM. Human papillomavirus type 11 DNA in papillary squamous cell lung carcinoma. Virchows Arch A Pathol Anat Histopathol 1990;417:457-461.
17 DiLorenzo TP, Tamsen A, Abramson AL, et al. Human papillomavirus type 6a DNA in the lung carcinoma of a patient with recurrent laryngeal papillomatosis is characterized by a partial duplication. J Gen Virol 1992;73:423-428.

18 Katial RK, Ranlett R, Whitlock WL. Human papilloma virus associated with solitary squamous papilloma complicated by bronchiectasis and bronchial stenosis. Chest 1994;106:1887-1889.

19 Kawaguchi T, Matumura A, Iuchi K, et al. Solitary squamous papilloma of the bronchus associated with human papilloma virus type 11. Intern Med 1999;38: 817-819.

20 Hiroshima K, Toyozaki T, Iyoda A, et al. Ultrastructural study of intranuclear inclusion bodies of pulmonary adenocarcinoma. Ultrastruct Pathol 1999;23: 383-389.

21 Tsuhako K, Nakazato I, Hirayasu T, et al. Human papillomavirus DNA in carcinoma of the lung. J Clin Pathol 1998;51:741-749.

22 Colby TV, Koss MN, Travis WD. Tumours of the lower respiratory tracts In: Rosai J (ed). Atlas of Tumor Pathology. Armed Forces Institute of Pathology: Washington, DC, 1995, pp 279-286.

23 Brouchet L, Valmary S, Dahan M, et al. Detection of oncogenic virus genomes and gene products in lung carcinoma. Br J Cancer 2005;92:743-746.

24 Noutsou A, Koffa M, Ergazaki M, et al. Detection of human papillomavirus (HPV) and K-ras mutations in human lung carcinomas. Int J Oncol 1996;8: 1089-1093.

25 Miasko A, Niklinska W, Niklinski J, et al. Detection of human papillomavirus in non-small cell lung carcinoma by polymerase chain reaction. Folia Histochem Cytobiol 2001;39:127-128.

26 Willey JC, Broussoud A, Sleemi A, et al. Immortalization of normal human bronchial epithelial cells by human papillomaviruses 16 or 18. Cancer Res 1991;51 5370-5377.

27 De Silva R, Whitaker NJ, Rogan EM, et al. HPV-16 E6 and E7 genes, like SV40 early region genes, are insufficient for immortalization of human mesothelial and bronchial epithelial cells. Exp Cell Res 1994;213: 418-427.

28 Viallet J, Liu C, Emond J, et al. Characterization of human bronchial epithelial cells immortalized by the E6 and E7 genes of human papillomavirus type 16. Exp Cell Res 1994;212:36-41.

29 Kinjo T, Kamiyama K, Chinen K, et al. Squamous metaplasia induced by transfection of human papillomavirus DNA into cultured adenocarcinoma cells. J Clin Pathol: Mol Pathol 2003;56:97-108.

30 Kinoshita I, Dosaka-Akita H, Shindoh M, et al. Human papillomavirus type 18 DNA and E6-E7 mRNA are detected in squamous cell carcinoma and adenocarcinoma of the lung. Br J Cancer 1995;71:344-349. 